\title{
Faktor-Faktor Yang Mempengaruhi Harga Saham Perusahaan Sub Sektor Property dan Real Estate
}

\author{
Delala Yuvita Sari ${ }^{1}$, Riana Rahmawati Dewi ${ }^{2}$, Rosa Nikmatul Fajri ${ }^{3}$ \\ 1,2,3 Universitas Islam Batik Surakarta, JL. KH. Agus Salim No.10, Jawa Tengah, Indonesia \\ Correspondence email: delala.yuvita@gmail.com
}

\begin{abstract}
Abstrak. Penelitian ini bertujuan untuk untuk menganalisis pengaruh return on asset (ROA), return on equity (ROE), earnings per share (EPS), current ratio (CR), debt to equity ratio (DER) terhadap harga saham. Teknik pengambilan sampel menggunakan purposive sampling. Berdasarkan purposive sampling yang telah dilakukan diperoleh sampel 34 perusahaan sub sektor property dan real estate yang terdaftar di Bursa Efek Indonesia periode 2016-2018 sesuai dengan kriteria yang telah ditentukan, sehingga total keseluruhan sampel berjumlah 102 yang siap untuk diolah. Metode analisa data yang digunakan dalam penelitian ini adalah analisis regresi linier berganda. Hasil penelitian ini membuktikan bahwa variabel earnings per share berpengaruh positif dan signifikan terhadap harga saham. Sebaliknya variabel current ratio berpengaruh negatif dan signifikan terhadap harga saham, sedangkan variabel return on asset, return on equity, debt to equity ratio tidak berpengaruh terhadap harga saham.
\end{abstract}

Kata kunci : CR; DER; EPS; Harga Saham; ROA; ROE

Abstract. This study aims to analyze the effect of return on assets (ROA), return on equity (ROE), earnings per share (EPS), current ratio $(C R)$, debt to equity ratio (DER) on stock prices. The sampling technique uses purposive sampling. Based on purposive sampling, 34 samples of property and real estate companies listed on the Indonesia Stock Exchange for the period of 2016-2018 were obtained in accordance with predetermined criteria, so that the total sample of 102 total were ready to be processed. The data analysis method used in this study is multiple linear regression analysis. The results of this study prove that earnings per share variable has a positive and significant effect on stock prices. Conversely the current ratio variable has a negative and significant effect on stock prices, while the variable return on assets, return on equity, debt to equity ratio has no effect on stock prices.

Keywords : CR; DER; EPS; ROA; ROE; Stock Price

\section{PENDAHULUAN}

Pada negara maju dan berkembang, bisnis property dan real estate sedang mengalami pertumbuhan pesat hal ini juga terjadi di Indonesia. Saham property dan real estate di Indonesia mulai diminati ketika tahun 2000, hal itu menyebabkan banyak perusahaan melakukan listing di Bursa Efek Indonesia agar saham perusahaan dapat dibeli investor. Pertumbuhan ekonomi di Indonesia tumbuh sekitar 5\% per tahun salah satu penunjangnya oleh sub sector property dan real estate. Hal ini membuat peneliti menjadikan perusahaan property dan real estate sebagai objek yang akan diteliti. Dengan demikian peneliti mengambil objek penelitian yaitu perusahaan property dan real estate yang terdaftar di Bursa Efek Indonesia tahun 2016 - 2018. Ada 48 perusahaan yang terdapat dalam sub sector property dan real estate di Bursa Efek Indonesia tahun 2016 - 2018 (www.sahamok.com).

Tabel 1. Presentase perbandingan variabel pertahun

\begin{tabular}{cccc}
\hline Tahun & $\mathbf{2 0 1 6}$ & $\mathbf{2 0 1 7}$ & $\mathbf{2 0 1 8}$ \\
\hline ROA (\%) & 0,50 & 0,19 & 0,13 \\
ROE (\%) & 0,27 & 0,48 & 0,29 \\
EPS (\%) & 95 & 208 & 44 \\
CR (\%) & 3,1 & 3,8 & 3,1 \\
DER (\%) & 4,6 & 4,4 & 4,1 \\
\hline
\end{tabular}

Sumber: IDX (data diolah peneliti, 2019)
Berdasarkan hasil perhitungan diatas return on asset (ROA) dalam 3 (tiga) tahun terakhir mengalami penurunan disebabkan kurangnya kemampuan perusahaan dalam menghasilkan laba. Untuk return on equity (ROE) ditahun 2016-2017 mengalami peningkatan sedangkan ditahun 2018 mengalami penurunan, kondisi ini berarti profitabilitas perusahaan cenderung tidak stabil. Sementara earnings per share (EPS) ditahun 2016-2017 mengalami peningkatan, sedangkan 2018 mengalami penurunan hal ini karena naik turunnya minat investor dalam menanamkan modalnya. Pada current ratio (CR) juga sama dengan return on equity (ROE) dan earnings per share (EPS) dikarenakan tidak stabilnya kemampuan perusahaan dalam membayar jangka pendek. Dan untuk debt to equity ratio (DER) terus mengalami penurunan hal ini berarti penggunaan hutang sebagai modal kerja perusahaan tidak stabil.

Dalam hal ini, penulis memilih rasio return on asset (ROA) dan ROE sebagai faktor yang mempengaruhi harga saham, karena return on asset (ROA) dan return on equity (ROE) merupakan rasio yang mewakili pengambilan atas seluruh aktivitas perusahaan. Sementara earnings per share (EPS) dipilih karena earnings per share (EPS) menunjukkan berapa rupiah laba yang diterima investor atas setiap lembar 
sahamnya. Peneliti juga meneliti current ratio (CR) karena tingkat likuiditas perusahaan sangat diperhatikan oleh para investor, likuiditas jangka pendek yang tinggi akan memberikan keyakinan kepada investor terhadap kemampuan perusahaan membayar dividen. Dan debt to equity ratio (DER) dipilih karena utang jangka panjang untuk membiayai perluasan perusahaan atau modernisasi dari perusahaan karena kebutuhan modal untuk keperluan tersebut.

Dalam penelitian yang dilakukan Safitri (2016) yang menyatakan bahwa ROA berpengaruh terhadap harga saham, sedangkan Amalya (2018) tidak berpengaruh secara signifikan terhadap harga saham. Return On Equity (ROE) memiliki pengaruh positif dan signifikan terhadap harga saham, sedangkan penelitian Sari \& Meirina (2017) berpengaruh negatif dan signifikan terhadap harga saham. Hasil penelitian Tejaningtyas et al. (2016) menemukan bahwa variable earnings per share mempunyai pengaruh positif terhadap harga saham. Penelitian Tyas \& Saputra (2016) secara parsial tidak mempunyai pengaruh signifikan terhadap harga saham, sedangkan Ponggohong et al. (2016) bahwa variable Current Ratio berpengaruh terhadap harga saham. Menurut penelitian Manoppo et al. (2017) CR tidak berpengaruh terhadap harga saham, sedangkan Ayu Savitri et al. (2016) menemukan bahwa debt to equity ratio berpengaruh terhadap harga saham. Sedangkan menurut Rani \& Diantini (2015) debt to equity ratio tidak berpengaruh terhadap harga saham.

Berdasarkan uraian diatas peneliti bermaksud meneliti pengaruh return on asset (ROA), return on equity (ROE), earnings per share (EPS), current ratio (CR), debt to equity ratio (DER). Dalam penelitian ini peneliti mengambil data dari laporan sub sektor property dan real estate yang terdaftar di BEI Periode 2016-2018 sebagai bahan penelitian. Dengan adanya perbedaan harga saham dari setiap perusahaan dan hasil penelitian terdahulu, maka penulis mengambil judul "Faktor Faktor Yang Mempengaruhi Harga Saham Perusahaan Sub Sektor Property Dan Real Estate".

\section{METODE}

Jenis penelitian yang digunakan dalam penelitian ini adalah penelitian kuantitatif yang dapat diartikan sebagai metode penelitian yang berlandaskan pada filsafat positivisme, yang digunakan untuk meneliti populasi dan sampel tertentu (Sugiyono, 2013). Data yang digunakan dalam penelitian ini adalah data sekunder yang diambil dari laporan keuangan perusahaan sub sektor property dan real estate yang terdaftar di Bursa Efek Indonesia (BEI) periode 20162018. Responden dalam penelitian ini adalah seluruh perusahaan sub sektor property dan real estate dari Bursa Efek Indonesia (BEI) periode 2016-2018.

Populasi dalam penelitian ini adalah seluruh perusahaan sub sektor property dan real estate sebanyak 48 (empat puluh delapan) perusahaan. Pengambilan sampel dalam penelitian ini menggunakan metode purposive sampling, artinya metode penentuan sampel dengan ktiteria atau pertimbangan tertentu (Sugiyono, 2013). Sampel dalam penelitian ini sebanyak 102 (seratus dua) data observasi perusahaan sub sektor property dan real estate, yaitu 34 (tiga puluh empat) perusahaan dikalikan 3 tahun (periode 2016-2018). Dalam upaya mengolah data serta menarik kesimpulan maka peneliti menggunakan program SPSS version 20 for windows. Teknik analisis data menggunkaan regresi linier berganda.

\section{HASIL DAN PEMBAHASAN Hasil}

Tabel 2. Hasil statistic deskriptif

\begin{tabular}{lccc}
\hline Keterangan & $\mathrm{N}$ & Mean & Std.Deviation \\
\hline ROA & 102 & -3.2607 & 1.11013 \\
ROE & 102 & -2.7057 & 1.06950 \\
EPS & 102 & 3.1015 & 2.04904 \\
CR & 102 & .7521 & .74593 \\
DER & 102 & -1.0598 & 1.31629 \\
HS & 102 & 6.3275 & 1.48227 \\
Valid N & & &
\end{tabular}

Sumber: SPSS 20

Berdasarkan hasil statistik deskriptif tabel diatas dapat diketahui bahwa variabel ROA nilai mean sebesar -3.2607 dan standar deviation sebesar 1.11013. Variabel ROE nilai mean sebesar -2.7057 dan standar deviation sebesar 1.06950. Variabel EPS nilai mean sebesar 3.1015 dan standar deviation sebesar 2.04904. . Variabel CR nilai mean sebesar 0.7521 dan standar deviation sebesar 0.74593 . Variabel DER nilai mean sebesar -1.0598 dan standar deviation sebesar 1.31629. Variabel Harga Saham nilai mean sebesar 6.3275 dan standar deviation sebesar 1.48227 .

Tabel 3. Hasil Uji Normalitas

\begin{tabular}{lcc}
\hline & Unstandardized Residual & Kesimpulan \\
\hline $\begin{array}{l}\text { Asymp. Sig. } \\
\text { (2-tailed) }\end{array}$ & 0,051 & Normal \\
\hline
\end{tabular}

\section{Sumber: SPSS 20}

Berdasarkan hasil uji normalitas Kolmogorov Smirnov pada tabel diatas dapat diketahui nilai Asymp.Sig (2-tailed) sebesar 0,051 yang artinya bahwa nilai tersebut lebih dari 0,05 yang berarti bahwa data berdistribusi normal.

Tabel 4. Hasil Uji Multikolinieritas

\begin{tabular}{cccc}
\hline Variabel & Tolerence & VIF & Keterangan \\
\hline ROA & .238 & 4.210 & $\begin{array}{c}\text { Tidak ada } \\
\text { Multikolinieritas } \\
\text { ROE }\end{array}$ \\
EPS & .273 & 3.663 & $\begin{array}{c}\text { Tidak ada } \\
\text { Multikolinieritas } \\
\text { Tidak ada } \\
\text { Multikolinieritas }\end{array}$
\end{tabular}




\begin{tabular}{cccc} 
CR & .959 & 1.043 & $\begin{array}{c}\text { Tidak ada } \\
\text { Multikolinieritas } \\
\text { DER }\end{array}$ \\
& .929 & 1.076 & $\begin{array}{c}\text { Tidak ada } \\
\text { Multikolinieritas }\end{array}$ \\
\hline
\end{tabular}

Dari hasil uji multikolinieritas bahwa variabel Return On Asset (ROA), Return On Equity (ROE), Earnings Per Share (EPS), Current Ratio (CR), Debt to Equity Ratio (DER) memiliki variance inflation factor (VIF) kurang

dari 10 (VIF < 10) atau nilai tolerencenya lebih dari 0,1 , sehingga dapat disimpulkan bahwa tidak terjadi multikolinieritas dalam penelitian ini.

Tabel 5. Hasil Uji Autokorelasi

\begin{tabular}{llcc}
\hline Durbin-Watson & $\mathrm{dU}$ & $\mathrm{dL}$ & Kesimpulan \\
\hline 1,914 & 1,781 & 1,576 & $\begin{array}{c}\text { Tidak ada } \\
\text { autokorelasi }\end{array}$ \\
\hline
\end{tabular}

Sumber: SPSS 20

Berdasarkan hasil pengujian Autokorelasi pada tabel dengan metode Durbin Watson (dW) menunjukkan bahwa nilai d sebesar 1,914, sedangkan nilai dL adalah 1,576, dU sebesar 1,781, 4-dU sebesar 2,219, dan 4-dL sebesar 2,424 dengan melihat ketentuan yang ada bahwa nilai d terletak pada $\mathrm{dU}<\mathrm{dW}<4$-dU, maka dapat disimpulkan bahwa tidak ada Autokorelasi dalam model regresi.

Tabel 6. Hasil Uji Heteroskedastisitas

\begin{tabular}{cccc}
\hline Model & Sig. & P-value & Kesimpulan \\
\hline ROA & .949 & P $>0,05$ & Tidak ada heteroskedastisitas \\
ROE & .857 & P $>0,05$ & Tidak ada heteroskedastisitas \\
EPS & .307 & $\mathrm{P}>0,05$ & Tidak ada heteroskedastisitas \\
CR & .737 & $\mathrm{P}>0,05$ & Tidak ada heteroskedastisitas \\
DER & .494 & $\mathrm{P}>0,05$ & Tidak ada heteroskedastisitas \\
\hline
\end{tabular}

Sumber: SPSS 20

Dari hasil uji heteroskedastisitas bahwa variabel return on asset (ROA), return on equity (ROE), earnings per share (EPS), current ratio (CR), debt to equity ratio (DER) memiliki nilai signifikansi $>0,05$ sehingga dapat disimpulkan bahwa tidak terjadi masalah heteroskedastisitas dalam penelitian ini.

Tabel 7. Uji Model Regresi

\begin{tabular}{ccc}
\hline Variabel & Koefisien Regresi & Standart Error \\
\hline Konstanta & 6.873 & .648 \\
ROA & .269 & .241 \\
ROE & .071 & .233 \\
EPS & .228 & .074 \\
CR & -.369 & .179 \\
DER & -.089 & .103 \\
\hline
\end{tabular}

Sumber: SPSS 20

Berdasarkan hasil analisis regresi linier berganda pada tabel diatas, maka di dapat persamaan analisis regresi linier berganda sebagai berikut :
Harga Saham $=6.873+0.269 \mathrm{ROA}+0.071 \mathrm{ROE}+$ 0.228 EPS $-0.369 \mathrm{CR}-0.089$ DER

Persamaan analisis regresi linier berganda yang terbentuk diatas tersebut memberikan pengertian sebagai berikut:

a. Harga Saham (Konstanta = a) adalah 6.873 mempunyai arti harga saham akan bernilai 66.873 jika variabel ROA, ROE, EPS, CR, DER bernilai 0 atau constant.

b. Return On Assets $(\mathrm{ROA})=\mathrm{X}_{1}$ mempunyai koefisien regresi sebesar 0.269 , mempunyai arti apabila ROA mengalami kenaikan $1 \%$ maka harga saham mengalami kenaikan 0.269 dengan anggapan variabel lainnya konstan.

c. Return On Equity (ROE) $=\mathrm{X}_{2}$ mempunyai koefisien regresi sebesar 0.071, mempunyai arti apabila $\mathrm{ROE}$ mengalami kenaikan $1 \%$ maka harga saham mengalami kenaikan 0.071 dengan anggapan variabel lainnya konstan.

d. Earning Per Share (EPS) $=\mathrm{X}_{3}$ mempunyai koefisien regresi sebesar 0.228 , mempunyai arti apabila EPS mengalami kenaikan $1 \%$ maka harga saham mengalami kenaikan 0.228 dengan anggapan variabel lainnya konstan.

e. Current Ratio $(\mathrm{CR})=\mathrm{X}_{4}$ mempunyai koefisien regresi sebesar -0.369 , mempunyai arti apabila $\mathrm{CR}$ mengalami kenaikan $1 \%$ maka harga saham mengalami penurunan -0.369 dengan anggapan variabel lainnya konstan.

f. Debt to Equity Ratio $(\mathrm{DER})=\mathrm{X}_{5}$ mempunyai koefisien regresi sebesar -0.089 , mempunyai arti apabila DER mengalami kenaikan 1\% maka harga saham mengalami penurunan -0.089 dengan anggapan variabel lainnya konstan.

Tabel 8. Uji Kelayakan Model (Uji F)

\begin{tabular}{lllll}
\hline Model & F $_{\text {hitung }}$ & $\mathrm{F}_{\text {tabel }}$ & Sig & Hasil \\
\hline 1 & 6.651 & 2.303 & 0.000 & Model Layak \\
\hline
\end{tabular}

Sumber: SPSS 20

Dari tabel diperoleh bahwa $F_{\text {hitung }} 6.651$ dengan tingkat signifikansi 0.000 . Berdasarkan nilai signifikansi dapat dilihat bahwa nilai signifikansi $<0.05(0.000<$ 0.05). Dapat disimpulkan bahwa model memenuhi kelayakan.

Tabel 9. Uji Hipotesis (Uji t)

\begin{tabular}{lllll}
\hline Model & $\mathrm{t}_{\text {hitung }}$ & $\mathrm{t}_{\text {tabel }}$ & Sig. & Kesimpulan \\
\hline ROA & 1.115 & 1.985 & 0.268 & H1 Ditolak \\
ROE & 0.304 & 1.985 & 0.762 & H2 Ditolak \\
EPS & 3.074 & 1.985 & 0.003 & H3 Diterima \\
CR & -2.070 & 1.985 & 0.041 & H4 Diterima \\
DER & -0.863 & 1.985 & 0.390 & H5 Ditolak \\
\hline
\end{tabular}

Sumber: Lampiran 20

Berdasarkan hasil t Test adalah sebagai berikut :

1. Pengaruh Return On Assets yang diuji terhadap harga saham menunjukkan hasil bahwa nilai $t_{\text {hitung }}$ sebesar 
1.115 dengan nilai signifikan variabel 0.268 dan $t_{\text {tabel }}$ sebesar 1.985 dengan taraf signifikannya $\alpha=0.05$. Dari data tersebut menunjukkan bahwa $\mathrm{t}_{\text {hitung }}<\mathrm{t}_{\text {tabel }}$ $(1.115<1.985)$ dengan nilai signifikan $0.268>0.05$. Maka H1 ditolak dan Ho diterima.

2. Pengaruh Return On Equity yang diuji terhadap harga saham menunjukkan hasil bahwa nilai $t_{\text {hitung }}$ sebesar 0.304 dengan nilai signifikan variabel 0.762 dan $t_{\text {tabel }}$ sebesar 1.985 dengan taraf signifikannya $\alpha=0.05$. Dari data tersebut menunjukkan bahwa $\mathrm{t}_{\text {hitung }}<\mathrm{t}_{\text {tabel }}$ $(0.304<1.985)$ dengan nilai signifikan $0.762>0.05$. Maka H2 ditolak dan Ho diterima.

3. Pengaruh Earning Per Share yang diuji terhadap harga saham menunjukkan hasil bahwa nilai thitung sebesar 3.074 dengan nilai signifikan variabel 0.003 dan $t_{\text {tabel }}$ sebesar 1.985 dengan taraf signifikannya $\alpha=$ 0.05 . Dari data tersebut menunjukkan bahwa $t_{\text {hitung }}>$ $\mathrm{t}_{\text {tabel }}(3.074>1.985)$ dengan nilai signifikan $0.003<$ 0.05. Maka H3 diterima dan Ho ditolak

4. Pengaruh Current Ratio yang diuji terhadap harga saham menunjukkan hasil bahwa nilai $t_{\text {hitung }}$ sebesar 2.070 (arah negatif) dengan nilai signifikan variabel 0.041 dan tabel sebesar 1.985 dengan taraf signifikannya $\alpha=0.05$. Dari data tersebut menunjukkan bahwa $t_{\text {hitung }}>t_{\text {tabel }}(2.070>1.985)$ dengan nilai signifikan $0.020<0.05$. Maka H4 diterima dan Ho ditolak

5. Pengaruh Debt to Equity Ratio yang diuji terhadap harga saham menunjukkan hasil bahwa nilai thitung sebesar -0.863 (arah negatif) dengan nilai signifikan variabel 0.390 dan $t_{\text {tabel }}$ sebesar 1.985 dengan taraf signifikannya $\alpha=0.05$. Dari data tersebut menunjukkan bahwa $\mathrm{t}_{\text {hitung }}<\mathrm{t}_{\text {tabel }}(0.863<1.985)$ dengan nilai signifikan $0.390>0.05$. Maka H5 ditolak dan Ho diterima.

Tabel 10. Uji Koefisien Determinasi $\left(\mathrm{R}^{2}\right)$

\begin{tabular}{cccc}
\hline $\mathrm{R}$ & $\mathrm{R}$ Square & $\begin{array}{c}\text { Adjusted R } \\
\text { Square }\end{array}$ & $\begin{array}{c}\text { Std. Error of the } \\
\text { Estimate }\end{array}$ \\
\hline $.507^{\mathrm{a}}$ & .257 & .219 & 1.31028 \\
\hline Sumber : SPSS 20 & &
\end{tabular}

Berdasarkan tabel diatas, nilai adjusted $\mathrm{R}^{2}$ sebesar 0,219. Dengan demikian dapat disimpulkan bahwa kemampuan variabel independent dalam menjelaskan variabel dependen sebesar $21,9 \%$. Sisanya sebesar 78,1\% dijelaskan oleh variabel lain diluar model.

\section{Pembahasan}

Pengaruh return on assets (ROA) terhadap harga saham Hasil penelitian menunjukkan bahwa variabel ROA tidak berpengaruh terhadap harga saham. Hal ini dibuktikan dengan hasil hipotesa yang secara statistik variabel ROA tidak mempengaruhi harga saham atau Ho ditolak. Semakin tinggi maupun rendah return on assets (ROA) tidak akan mempengaruhi harga saham, dikarenakan return on assets merupakan kemampuan untuk menghasilkan laba bersih pada perusahaan. Hal ini menunjukkan kurangnya efektif perusahaan dalam memanfaatkan aktiva dalam menghasilkan laba sehingga mengakibatkan investor kurang minat dalam menanamkan modal saham pada perusahaan sehingga mengakibatkan return on assets tidak berpengaruh terhadap harga saham.

Pengaruh return on equity (ROE) terhadap harga saham Hasil penelitian menunjukkan bahwa variabel ROE tidak berpengaruh terhadap harga saham. Hal ini dibuktikan dengan hasil hipotesa yang secara statistik variabel ROE tidak mempengaruhi harga saham atau $\mathrm{H} 0$ ditolak. Return On Equity tidak berpengaruh terhadap harga saham dikarenakan ROE mengalami penurunan dikarenakan laba bersih yang kurang dari modal perusahaan dan laba penjualan perusahaan yang kurang.

\section{Pengaruh earning per share (EPS) terhadap harga saham}

Hasil penelitian menunjukkan bahwa variabel EPS berpengaruh signifikan dan positif terhadap harga saham. Hal ini dibuktikan dengan hasil hipotesa yang secara statistik variabel EPS mempengaruhi harga saham atau Ho diterima. Semakin tinggi nilai earning per share yang dimiliki pada perusahaan maka semakin tinggi juga minat investor dalam menanamkan sahamnya. Hal ini dikarenakan EPS merupakan jumlah rupiah yang diperoleh menghasilkan setiap per lembar saham perusahaan.

\section{Pengaruh current ratio $(C R)$ terhadap harga saham}

Hasil penelitian menunjukkan bahwa variabel $\mathrm{CR}$ berpengaruh signifikan dan negatif terhadap harga saham. Hal ini dibuktikan dengan hasil hipotesa yang secara statistik variabel CR mempengaruhi harga saham atau Ho diterima. Semakin tinggi CR maka semakin besar kemampuan perusahaan dalam melunasi hutanghutangnya. Maka para kreditor dapat mempertimbangkan untuk memberikan pinjaman bagi para investor.

\section{Pengaruh debt to equity ratio (DER) terhadap harga saham}

Hasil penelitian menunjukkan bahwa variabel DER tidak berpengaruh terhadap harga saham. Hal ini dibuktikan dengan hasil hipotesa yang secara statistik variabel DER tidak mempengaruhi harga saham atau Ho ditolak. Semakin tinggi DER maka hutang yang dimiliki perusahaan tinggi juga, hal ini menandakan pembayaran ekuitas menggunakan hutang juga tinggi. Hal ini menyebabkan investor menghindari saham perusahaan tersebut.

\section{SIMPULAN}

Tujuan penelitian ini adalah untuk menganalisis pengaruh return on asset (ROA), return on equity (ROE), earnings per share (EPS), current ratio (CR), debt to equity ratio (DER) terhadap harga saham 
perusahaan sub sektor property dan real estate yang terdaftar di Bursa Efek Indonesia (BEI) periode 20162018. Jenis penelitian ini adalah penelitian kuantitatif. Teknik pengambilan sampel dengan purposive sampling, diperoleh sebanyak 34 perusahaan sub sektor property dan real estate selama periode tiga tahun. Hasil penelitian ini menyimpulkan bahwa variabel earnings per share (EPS) berpengaruh signifikan positif terhadap harga saham dan variabel current ratio (CR) berpengaruh signifikan negatif terhadap harga saham, sedangkan variabel return on asset (ROA), return on equity (ROE), debt to equity ratio (DER) tidak berpengaruh terhadap harga saham perusahaan sub sektor property dan real estate. Nilai Adjusted $\mathrm{R}^{2}$ sebesar 0,219 yang artinya nilai perusahaan dipengaruhi oleh variabel return on asset (ROA), return on equity (ROE), earnings per share (EPS), current ratio (CR), debt to equity ratio (DER) sebanyak 21,9\% sedangkan sisanya $78,1 \%$ dipengaruhi oleh variabel lain diluar model.

\section{DAFTAR PUSTAKA}

Amalya, N. T. (2018). Pengaruh Return On Asset, Return On Equity, Net Profit Margin Dan Debt To Equity Ratio Terhadap Harga Saham. Jurnal Sekuritas, 1(3).

Ayu Savitri , L. (2016). Pengaruh Leverage, Price earning, Dividend Payout terhadap Harga saham pada perusahaan otomotif.

Manoppo, V. C., Tewal, B., \& Hasan Jan, A. B. (2017). Pengaruh Current Ratio, DER, ROA dan NPM Terhadap Harga Saham Pada Perusahaan Food And Beverages Yang Terdaftar Di BEI (Periode 2013-2015). Jurnal EMBA, 5(2), 1813-1822 .

Ponggohong J.O, Murni, S, \& Mangantar M. (2016). Pengaruh Kinerja Keuangan Terhadap Harga Saham (Studi Pada Perusahaan Ritel Yang Terdaftar di BEI Tahun 2010-2013). Jurnal Berkala Ilmiah Efisiensi, 883.

Putra, A. P. (2013). "Pengaruh Kinerja Keuangan terhadap Harga Saham Perusahaan BUMN (Non Bank) yang terdaftar di BEI". Diponegoro Journal of Social and Politic Tahun 2013, 1-9.

Rani, K. S., \& Diantini, N. A. (2015). Pengaruh Kinerja Keuangan Perusahaan Terhadap Harga Saham Dalam Indeks LQ45 di BEI. E-Jurnal Manajemen Unud, 6.

Ratih, D. E. (2013). "Pengaruh EPS, PER, DER dan ROE terhadap Harga Saham pada Perusahaan Sektor Pertambangan yang terdaftar di BEI". Diponegoro Journal of Social and Politic , 1-12.

Safitri. (2016). Pengaruh PER, ROA, dan DER terhadap Harga saham pada perusahaan sub sektor lembaga pembiayaan di Bursa Efek Indonesia. eJournal Administrasi Bisnis.

Sari , H. Z., \& Meirina H., A. D. (2017). Pengaruh Current Ratio (CR), Return On Equity (ROE),
Debt To Equity Ratio (DER), dan Earning Per Share (EPS) Terhadap Harga Saham (Pada Perusahaan Sub Sektor Property dan Real Estate di Bursa Efek Indonesia (BEI) Periode 2011-2015. Jurnal Ekonomika dan Manajemen, 6(2).

Tejaningtyas, R, \& S. (2016). Analisis Pengaruh Rasio Profitabilitas Terhadap Harga Saham Pada Perusahaan Real Estate Dan Property Yang Terdaftar Di Bursa Efek Indonesia Tahun 20122014. Jramb, Prodi Akuntansi, Fakultas Ekonomi, 2(2), 1-15.

Tyas, R. A., \& Saputra, R. S. (2016). Analisis Pengaruh Profitabilitas Terhadap Harga Saham (Studi Kasus Perusahaan Telekomunikasi Yang Terdaftar di Bursa Efek Indonesia (BEI) Periode 2012-2014). JURNAL ONLINE INSAN AKUNTAN, 77-91.

WWW.idx.com 